\title{
Species richness of Cladocera (Crustacea: Branchiopoda) in the Western Ghats of Maharashtra and Goa (India), with biogeographical comments
}

\author{
Sameer M. PADHYE,${ }^{1 *}$ Henri J. DUMONT ${ }^{2,3}$ \\ ${ }^{1}$ Wildlife Information Liaison Development Society, Coimbatore, 641035, Tamil Nadu, India; ${ }^{2}$ Department of Ecology and Hydrobiology, \\ Jinan University, Guangzhou, China; ${ }^{3}$ Biology Department, Ghent University, Gent, Belgium \\ *Corresponding author: sameer.m.padhye@gmail.com
}

\begin{abstract}
We assessed the species richness of Cladocera of the Western Ghats and surrounding areas of Maharashtra and Goa. Data of 230 samples from about 80 localities collected between 2009 and 2013 revealed 51 species in six families. Non-parametric estimators of species richness, Chao 2 and Jackknife 2, estimated the real total at 58 and 63 species, suggesting a coverage of $80 \%$ of the total species of the area. This fauna was compared with that of other countries from the Oriental region and found to be relatively species-poor, which is not in line with the biodiversity rich area status of the Western Ghats. Reasons for this are unclear. Complementarity among the cladoceran faunas of different countries belonging to the Oriental region increased with latitude and altitude. Along with the complementarity index, a comparison of family and generic occurrences of Cladocera revealed that family-level representation was similar between countries but species occurrences (like Daphnia species) varied. The subgenus Daphnia was reported only from Nepal while Ctenodaphnia was common in all countries of the Indian region. Biogeographically, the fauna was mainly composed of wide-ranging tropical species, mixed with some rare Palaearctic elements. Only two species were endemic to India. Of another one, the closest relative lives in Yucatan, Mexico, and thus has a tropical Amphi-Pacific distribution.
\end{abstract}

Key words: Biodiversity, Cladocera, India, Daphnia, Alona, Chydorus.

Received: June 2014. Accepted: August 2014.

\section{INTRODUCTION}

Data on the Cladocera of Asia are improving as more studies are being conducted on regional scales, leading to new discoveries. The fauna of Thailand, with over 100 species on record, is particularly well known (Maiphae et al., $2005,2008)$. A recent study of Laos also has resulted in the discovery of more than 70 species (Kotov et al., 2013). In contrast, advance in documenting the Cladocera of India has been slow. Of the ca. 700 species known globally (Kotov, 2011), the number living in India is actually unknown. Fernando and Kanduru (1984) listed 130 species, of which Michael and Sharma (1988) described only 89. One hundred thirty species have been recently listed by Chatterjee et al. (2013), but many records remain doubtful because Indian literature abounds with checklists riddled with identification errors. Within India, the cladoceran fauna of the North East is the best known (Sharma and Sharma, 1990, 2007, 2008, 2009, 2011), with over 60 species documented.

Comprehensive species richness data of Cladocera from the Western Ghats, a biodiversity-rich region (Myers et al., 2000; Mittermeier et al., 2005), are not available. The situation here is similar, with most studies focusing on faunal inventories and little attention to correct identification and nomenclature. There are a number of faunistic checklists of Cladocera from single localities from Maharashtra state (nearly $1 / 3$ of Western Ghats lies in Maharashtra) (Rane, 2002, 2009; Patil GP et al., 2008; Patil SS et al., 2008; Vanjare et al., 2010; Rane, 2013). Countless nomenclatural errors in these works render them useless and have only artificially inflated the species richness. Hence, our primary objective was to derive a first ever species richness estimate for the northern region of the Western Ghats (region lying in Maharashtra and Goa; referred henceforth as NWG). We also compared the fauna from NWG with some well-studied South and South East Asian regions, with special attention for the genus Daphnia. We also comment on the biogeography of selected species.

\section{METHODS}

\section{Study region}

The Western Ghats are a chain of hills spread over $1600 \mathrm{~km}$ across six different Indian states, with a few gaps in between (Mani, 1974) (Fig. 1A). The hills have an altitudinal range of $600-1000 \mathrm{~m}$ reaching $2000 \mathrm{~m}$ in the southern regions. The Western Ghats receive most of their rainfall during Monsoon (June-October). This amount varies with region (the southern region receives more than the north) (Mani, 1974). The sampling region for our study consisted of Western Ghats and adjoining areas in the states of Maharashtra and Goa (Fig. 1). 


\section{Sampling}

Sampling was performed from January 2009 to November 2013. Two hundred and thirty samples were collected from about 80 different habitats located between 495 and $1309 \mathrm{~m}$ asl covering the complete altitudinal range of NWG. Different types of habitats (from rock-pools to large water reservoirs) were sampled and an attempt was made to sample habitats more than once. Plankton tow-net and hand-net with mesh size of $52 \mu \mathrm{m}$ and $150 \mu \mathrm{m}$ were used for collections. The tow-net consisted of an iron ring $10 \mathrm{~cm}$ in diameter, attached to about $300 \mathrm{~cm}$ of long nylon rope, fitted with a $10 \mathrm{~cm}$ (diameter) net of plankton mesh and provided with a $125-\mathrm{mL}$ plastic receptacle at the tail end. Hand net consisted of a circular plastic frame $(\mathrm{r}=7.5 \mathrm{~cm}$, $\mathrm{h}=6 \mathrm{~cm}$ ) having a net with a mesh size of $150 \mu \mathrm{m}$ with an extension to hold it. This net was particularly used for lit- toral samples. Samples were collected in plastic containers $(100 \mathrm{~mL})$ on the field itself and immediately fixed by using $5 \%$ formaldehyde or $70 \%$ ethanol.

\section{Identification}

Cladocerans were separated and dissected under a Stereomicroscope (Magnus MS 24; Lawrence \& Mayo Pvt. Ltd., Bangalore, India). Final examination of specimens was carried out under a compound microscope (Ch20i and CX41; Olympus, Tokio, Japan).Identifications were done using keys by Korovchinsky (1992) for Sididae, Benzie (2005) for Daphnia, Dumont and Pensaert (1983) for Scapholeberis, Orlova-Bienkowskaja (2001) for Simocephalus, Berner (1986) for Ceriodaphnia, Goulden (1968) for Moinidae, Smirnov (1992) for Macrothrichidae, Kotov and Štifter (2006) for Ilyocryptidae, Smirnov $(1971,1996)$ for

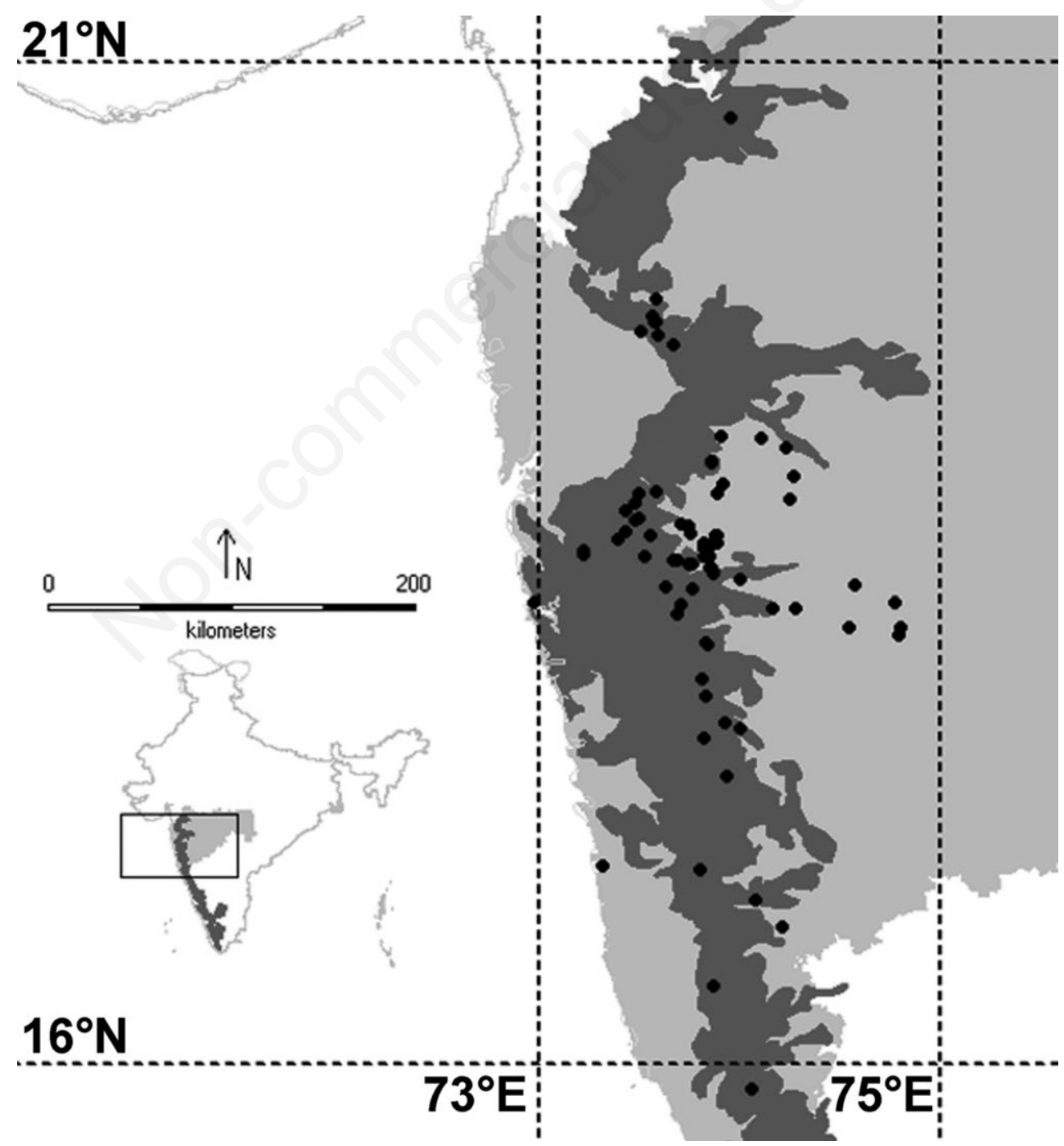

Fig. 1. Sampling region and localities of the study. Gray region represents Maharashtra and Goa states, India; dark gray shaded region represents the Western Ghats; black dots represent the localities (very closely spaced localities to the black dots not shown). 
Chydoridae. We also referred to papers on particular species if recent taxonomical work had been carried out on them.

\section{Species richness estimation}

Species richness was estimated using nonparametric (distribution-free) methods to evaluate true species richness from samples (Chao, 1987; Colwell and Coddington, 1994). This method is based on the relationship between singleton and doubletons observed in samples. We selected Chao 2 and Jackknife 2 indices for our data to estimate the true species number. EsimtateS (v9.1) (Colwell, 2013; http://viceroy.eeb.uconn.edu/EstimateS) was used to generate the species richness estimation using Chao2, Jackknife 2 indices. Estimation was carried out using biascorrected Chao 2 and Jackknife 2 indices. Five hundred randomizations per sample were carried out to get the standard deviation estimate around each data point.

\section{Complementarity index}

The complementarity index is a measure of non-similarity which can be used to compare different faunas and can provide a good resolution between two faunas (Colwell and Coddington, 1994; Dumont and Segers, 1996; Maiphae et al., 2005). It is given by the formula:

$\mathrm{C}_{\mathrm{jk}}=\mathrm{U}_{\mathrm{k}} / \mathrm{S}_{\mathrm{jk}}$ where $\mathrm{S}_{\mathrm{jk}}=\mathrm{S}_{\mathrm{j}}+\mathrm{S}_{\mathrm{k}}-\mathrm{V}_{\mathrm{k}}$

where:

$\mathrm{S}_{\mathrm{j}}$, species richness of habitat $\mathrm{j}$;

$\mathrm{S}_{\mathrm{k}}$, species richness of habitat $\mathrm{k}$;

$\mathrm{S}_{\mathrm{jk}}$, sum of species richness of habitats $\mathrm{j}$ and $\mathrm{k}$;

$\mathrm{V}_{\mathrm{ik}}$, species number shared between habitats $\mathrm{j}$ and $\mathrm{k}$;

$\mathrm{V}_{\mathrm{ik}}, \mathrm{Sj}+\mathrm{S}_{\mathrm{k}}-2 \mathrm{~V}_{\mathrm{k}}$;

$\mathrm{U}_{\mathrm{ik}}$, number of species unique to habitats $\mathrm{j}$ and $\mathrm{k}$.

It can be expressed as a percentage of non-similarity (=complementarity) between groups. Thus, two habitats with identical faunas would have $\mathrm{C}=0$, while habitats with totally different faunas would have $\mathrm{C}=100$ (Colwell and Coddington, 1994). Complementarity index was used to compare faunas between selected Asian countries. For comparisons between different geographical regions we used Maiphae et al., $(2005,2008)$ for Thailand; Dumont and Van de Velde (1977), Swar and Fernando (1979) and Manca et al. (2006) for Nepal and Fernando (1980) for Sri Lanka. Data for comparison of numbers of Daphniidae were taken from the same literature used for complementarity analysis.

\section{RESULTS}

Fifty one species were found (Tab. 1). Chydoridae was the most speciose family with species numbers two to three times that of other families, while Ilyocryptidae was represented by only one species. Forty percent of the species found were rare, ten species were abundant. Ily- ocryptus spinifer Herrick, 1882 was recorded in about 40 $\%$ of the sampled habitats followed by Leydigia (Neoleydigia) ciliata Gauthier, 1939 (36\%) and Simocephalus (Simocephalus) mixtus Sars, 1903 (30\%). Maximum species richness was in seen Alona Baird, 1843 and Chydorus Leach, 1816 with four species each, followed by subgenus Ctenodaphnia Dybowski \& Grochowski, 1895 and genus Macrothrix Baird, 1843 (each with three species). Species such as Dunhevedia serrata Daday, 1898, Kurzia (Kurzia) latissima (Kurz, 1875), and Moinodaphnia macleayi (King, 1853) were found in single samples and with 1-2 specimens. Daphnia (Ctenodaphnia) carinata and D. (C.) similoides Hudec, 1991were restricted to temporary pools formed on outcrops in NWG. D. (C.) lumholtzi G.O. Sars, 1885 on the other hand, was common in all types of habitats. Amongst moinids, Moina micrura Kurz, 1874 and Moina macrocopa (Strauss, 1820) were abundant in eutrophic waters, a trait well known in these species. Moinodaphnia macleayi (King, 1853) and Moina hemanti were seen in a single locality. Indialona ganapati Petkovski, 1966 was restricted to the limnetic zone of large reservoirs, a trait also mentioned by Kotov (2000). Camptocercus cf. vietnamensis Sinev, 2012, Notoalona globulosa (Daday, 1898) and Bosmina (Bosmina) longirostris (O.F. Muller, 1776) were only seen in rivers and lakes. Anthalona harti harti, Van Damme, Sinev et Dumont, 2011 was mostly restricted to ephemeral waters. The highest number of species was seen in Pashan, a small reservoir with 30 species.

The number of singletons (L) was 7 and doubletons (M) were 2 from the 230 samples. With those values, the Chao 2 estimator produced an estimate of 57.8 (58) species while Jackknife2 yielded 62.87 (63) species (Fig. 2). Thus, about $80 \%$ of the fauna was covered by our study. Complementarity between regions ranged from $49 \%$ to $81 \%$ and increased with distance and latitude (Tab. 2). Of the countries included in the comparison, NWG was similar with Sri Lanka and most distinct from Nepal. Proportion of distribution was similar for Anomopoda across the regions. Values varied at family and generic level (Tab. 3). Few species such as Diaphanosoma excisum Sars, 1885, Daphnia (Ctenodaphnia) lumholtzi, Moina micrura, Bosmina longirostris, Chydorus eurynotus Sars, 1901 and Chydorus sphaericus (O.F. Müller, 1776) s. lat. occurred in all compared regions. Three of the four compared regions (all except Nepal) shared many circumtropical species like Latonopsis australis Sars, 1888 s.lat., Macrothrix spinosa King, 1853, Dunhevedia serrata, Kurzia (Rostrokurzia) longirostris (Daday, 1898), Ephemeroporus barroisi (Richard 1894) and Pseudochydorus globosus (Baird, 1843) s. lat. At the same time spatially restricted elements were also reported, like Moina hemanti (dumonti-group) for NWG and Macrothrix pholpunthini Kotov, Maiphae \& Sanoamuang, 2005 and Armatalona macrocopa Sars, 1895 for Thailand. Chydorids 
consistently represented more than $50 \%$ of the total cladoceran fauna in all the studied regions with Alona and Chydorus the best represented genera (Tab. 3).

\section{Note on Daphniidae}

The total number of daphniid species was similar for NWG, Sri Lanka and Thailand (Fig. 3). Five species of Daphnia were observed in Nepal, including the only re- port of the subgenus Daphnia namely, Daphnia (Daphnia) longispina (O.F. Muller, 1776). The number of species decreased with latitude with only one Ctenodaphnia in Thailand and two in Sri Lanka. D. (C.) lumholtzi was observed in all regions. On the other hand, Thailand had the maximum number from genus Simocephalus Schoedler, 1858 with six species while Nepal had only two representatives of that genus.

Tab. 1. Cladoceran species found in the study and their relative occurrence.

\begin{tabular}{|c|c|c|}
\hline No. & Species & Relative occurrence \\
\hline 1 & Diaphanosoma excisum Sars, 1885 & A \\
\hline 2 & Diaphanosoma sarsi Richard, 1895 & $\mathrm{C}$ \\
\hline 3 & Latonopsis australis Sars, 1888 s.lat. & A \\
\hline 4 & Pseudosida szalayi (Daday, 1898) & $\mathrm{R}$ \\
\hline 5 & Ceriodaphnia cf. cornuta Sars, 1885 & $\mathrm{Ab}$ \\
\hline 6 & Ceriodaphnia quadrangula (O. F. Müller, 1785) & A \\
\hline 7 & Daphnia (Ctenodaphnia) carinata King, 1853 s.lat. & $\mathrm{R}$ \\
\hline 8 & Daphnia (Ctenodaphnia) similoides Hudec, 1991 & A \\
\hline 9 & Daphnia (Ctenodaphnia) lumholtzi Sars, 1885 & $\mathrm{R}$ \\
\hline 10 & Scapholeberis kingi Sars, 1901 & A \\
\hline 11 & Simocephalus (Simocephalus) mixtus Sars, 1903 & $\mathrm{Ab}$ \\
\hline 12 & Simocephalus (Coronocephalus) serrulatus (Koch, 1841) & $\mathrm{R}$ \\
\hline 13 & Moina $\mathrm{n} . \mathrm{sp}$. & $\mathrm{R}$ \\
\hline 14 & Moina micrura Kurz, 1874 & $\mathrm{C}$ \\
\hline 15 & Moina macrocopa (Straus, 1820) & $\mathrm{R}$ \\
\hline 16 & Moinodaphnia macleayi (King, 1853) & $\mathrm{R}$ \\
\hline 17 & Bosmina (Bosmina) longirostris (O. F. Muller, 1776) & $\mathrm{R}$ \\
\hline 18 & Bosminopsis deitersi Richard, 1895 & $\mathrm{R}$ \\
\hline 19 & Macrothrix spinosa King, 1853 & $\mathrm{Ab}$ \\
\hline 20 & Macrothrix triserialis (Brady, 1886) & $\mathrm{Ab}$ \\
\hline 21 & Macrothrix odiosa Gurney, 1916 & $\mathrm{R}$ \\
\hline 22 & Guernella cf. raphaelis Richard, 1892 & $\mathrm{R}$ \\
\hline 23 & Ilyocryptus spinifer Herrick, 1882 & $\mathrm{Ab}$ \\
\hline 24 & Alona affinis (Leydig, 1860) s.lat. & $\mathrm{R}$ \\
\hline 25 & Alona cheni Sinev, 2001 & A \\
\hline 26 & Alona cf. cambouei Guerney et Richard, 1893 & A \\
\hline 27 & Alona quadrangularis (O.F. Müller, 1776) s.lat. & $\mathrm{R}$ \\
\hline 28 & Anthalona harti harti, Van Damme, Sinev et Dumont, 2011 & A \\
\hline 29 & Coronatella $\mathrm{cf}$. rectangula Sars, 1862 & A \\
\hline 30 & Camptocercus cf. vietnamensis Sinev, 2012 & $\mathrm{R}$ \\
\hline 31 & Notoalona globulosa (Daday, 1898) & $\mathrm{R}$ \\
\hline 32 & Oxyurella singalensis (Daday, 1862) & $\mathrm{R}$ \\
\hline 33 & Leberis punctatus (Daday, 1898) & $\mathrm{Ab}$ \\
\hline 34 & Karualona cf. karua (King, 1853) & $\mathrm{Ab}$ \\
\hline 35 & Kurzia (Kurzia) latissima (Kurz, 1875) s. lat. & $\mathrm{R}$ \\
\hline 36 & Kurzia (Rostrokurzia) longirostris (Daday, 1898) & $\mathrm{Ab}$ \\
\hline 37 & Leydigia (Neoleydigia) ciliata Gauthier, 1939 & $\mathrm{Ab}$ \\
\hline 38 & Euryalona orientalis (Daday, 1898) & $\mathrm{R}$ \\
\hline 39 & Indialona ganapati Petkovski, 1966 & $\mathrm{C}$ \\
\hline 40 & Alonella cf. excisa (Fischer, 1854) & A \\
\hline 41 & Chydorus eurynotus Sars, 1901 & $\mathrm{Ab}$ \\
\hline 42 & Chydorus parvus Daday, 1898 & $\mathrm{C}$ \\
\hline 43 & Chydorus sphaericus (O.F. Müller, 1776) s.lat. & $\mathrm{R}$ \\
\hline 44 & Chydorus ventricosus Daday, 1898 & $\mathrm{C}$ \\
\hline 45 & Dadaya macrops (Daday, 1898) & $\mathrm{R}$ \\
\hline 46 & Dunhevedia crassa King, 1853 & $\mathrm{Ab}$ \\
\hline 47 & Dunhevedia serrata Daday, 1898 & $\mathrm{R}$ \\
\hline 48 & Ephemeroporus barroisi (Richard 1894) & $\mathrm{C}$ \\
\hline 49 & Picripleuroxus sp. & A \\
\hline 50 & Pleuroxus aduncus (Jurine, 1820) s.lat. & A \\
\hline 51 & Pseudochydorus globosus (Baird, 1843) s. lat. & $\mathrm{C}$ \\
\hline
\end{tabular}

$R$, rare (1-10 samples); $A$, average (11-25 samples); $C$, common (26-40); Ab, abundant (above 40 samples). 


\section{DISCUSSION}

Credible faunal data are restricted to a few habitats which have a long history of observations (Dumont and Segers, 1996) and a stable taxonomy. However, many cladoceran taxa from the tropics have an uncertain identity (Kotov et al., 2013). Southern Asia still trails in validly described cladoceran species when compared with other regions like Australia and Europe (Forró et al., 2008), and even Southeast Asia (Maiphae et al., 2005, 2008; Kotov et al., 2013). Sharma and Sharma (2005) stated that the limnological surveys from India include poor species inventories due to the general lack of taxonomic expertise, a statement which is still valid (Chatterjee et al., 2013). All this applies to almost all previous cladoceran studies from NWG region as well.

With ca. 130 species reported from India (an estimate yet again) (Chatterjee et al., 2013), the 51 species from NWG represent roughly $40 \%$ of total species richness known. This number compares well with a recent inventory of Maharashtra by Rane (2013), finding 58 species (considering only the number and not the validity of species) but was distinctly lower than South Thailand $(=72$; Maiphae et al., 2005), Laos (=70; Kotov et al., 2013), and comparable to Cameroon ( $=61$; Chiambeng and Dumont, $2005)$ in the impoverished African tropics. The number of species found can thus be said to be low for Asia, and certainly for a biodiversity rich area like the Western Ghats. The reasons for this lesser number might be due to incomplete or biased sampling and lack of systematic and/or repeated sampling of large water bodies, each of which should harbor about 50 cladoceran species at a time (Dumont and Segers, 1996). This low number could also reflect the fact that exotic environments like wet mosses and interstitial water, known to harbor unique taxa (Dumont, 1994), have not been included. Species living in such places could increase the expected species number. Endemic species may have a restricted distribution and hence are easy to be missed (Forró et al., 2008). Our finding of Moina hemanti is one such example (Padhye and Dumont, 2014). Another problem in finding the true richness is that some widely distributed species may contain hidden diversity (cryptic species). Cosmopolitanism in Cladocera has been abandoned in favor of regional endemism (Dumont,
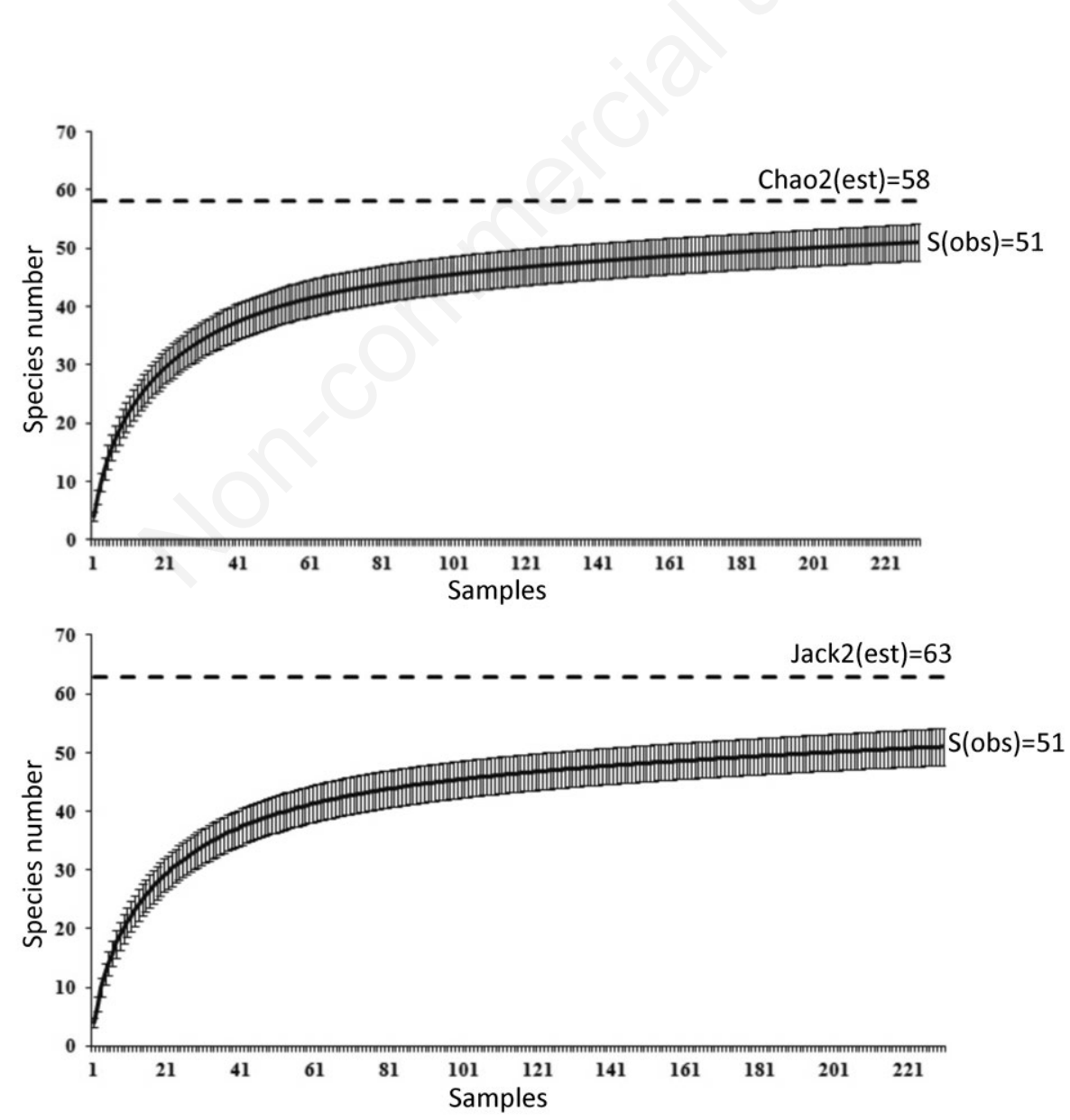

Fig. 2. Chao2 and Jackknife2 estimators of Cladocera species richness (black dashed line) against observed species richness (S (obs), black solid line). Each point is the mean of 500 estimates based on 500 randomizations of sample accumulation order. 
1980; Frey, 1986, 1987; Hudec, 1991; Sinev, 1999, 2001, 2011, 2012; Van Damme and Dumont, 2008; Petrusek et al., 2004; Belyaeva and Taylor, 2009; Kotov and Taylor, 2010; Van Damme et al., 2011). We observed several such species complexes and labeled them as $c f$. or s.lat. as their identity is yet to be established. Examples include Latonopsis australis, Moina micrura, Coronatella rectangula and Karualona karua. Disentangling these will increase the species richness. At the same time, it can be said that sampling effort for our study was relatively efficient as $80 \%$ of the fauna was recovered and only an estimated 8-10 species were missed given the sample size (for values refer to Fig. 2). It has been shown that Chao 2 and Jackknife 2 estimators are efficient in assessment of cladoceran diversity with respect to incidence based data (Dumont and Segers, 1996; Maiphae et al., 2005, 2008; Chiambeng and Dumont, 2005; Kotov et al., 2013).

NWG cladoceran species distribution varied from broadly distributed to point endemics. Of the species observed in the study, a large fraction was circumtropical with species such as Latonopsis australis s.lat., Diaphanosoma sarsi Richard, 1895, Bosmina longirostris, Guernella raphaelis Richard, 1892, Macrothrix spinosa King, 1853, Macrothrix triserialis (Brady, 1886), Kurzia (Rostrokurzia)longirostris, Euryalona orientalis (Daday, 1898), Dadaya macrops (Daday, 1898), Chydorus parvus Daday, 1898 and Chydorus ventricosus Daday, 1898. Alona cheni Sinev, 2001, Camptocercus vietnamensis,
Leberis punctatus (Daday, 1898), Indialona ganapati and Moina n. sp. represented the Oriental fauna (Maiphae et al., 2008; Sinev, 2012; Chatterjee et al., 2013; Kotov et al., 2005; Korovchinsky, 2013; Padhye and Dumont, 2014). Moina n. sp. is part of a group of species with a tropical Amphi-Pacific distribution (see Van Damme and Sinev, 2013) and its closest relative (M. dumonti) is found 10,000 km away in South America (Kotov et al., 2005; Padhye and Dumont, 2014). Taxa known to be species complexes with a global distribution like Chydorus sphaericus s. lat., Alona quadrangularis (O.F. Müller, 1776) s. lat., Alona affinis (Leydig, 1860) s.lat. (Van Damme and Dumont, 2008; Belyaeva and Taylor, 2009; Van Damme et al., 2010) were rarely seen. Regional forms of these species have a comparably limited distribution [e.g., Alona kotovi Sinev, 2012 from Vietnam is a Southeast Asian species from the A. quadrangularis species complex (Sinev, 2012)]. Also, chydorids like Pleuroxus aduncus (Jurine, 1820) s.lat., Picripleuroxus sp. and Kurzia (Kurzia) latissima, known from characteristic habitats (acid ponds and bogs) in the Palaearctic region (Chiambeng and Dumont, 2005), were uncommon in the collections, being seen in neutral ponds and riverine habitats only. Regional endemism could again perhaps help explain the occurrence of these species in NWG. Alternatively, the ejected relicts hypothesis of Korovchinsky (2006) states that many such cladoceran species are relicts of a Pre-Pleistocene continuous distribution. This hypoth-

Tab. 2. Complementarity values of the regions expressed in percentages.

\begin{tabular}{lccc}
\hline & Northern Western Ghats & Sri Lanka & Thailand \\
\hline Northern Western Ghats & 0 & 49 & 65 \\
Sri Lanka & - & 0 & 73 \\
Thailand & - & - & 64 \\
Nepal & - & - & 0 \\
\hline
\end{tabular}

Tab. 3. Comparison of cladoceran fauna (in percentage) to other South and South East Asian regions w.r.t. order, family and genera (only most speciose families and genera given).

\begin{tabular}{|c|c|c|c|c|}
\hline Richness (relative proportion to total species) & Northern Western Ghats & Sri Lanka & Nepal & Thailand \\
\hline \multicolumn{5}{|l|}{ Order } \\
\hline Anomopoda & 92.16 & 91.67 & 94.87 & 91.35 \\
\hline Ctenopoda & 7.84 & 8.33 & 5.13 & 8.65 \\
\hline \multicolumn{5}{|l|}{ Families } \\
\hline Chydoridae & 52.94 & 56.25 & 56.41 & 61.54 \\
\hline Daphniidae & 15.69 & 14.58 & 28.21 & 6.7 \\
\hline \multicolumn{5}{|l|}{ Genera } \\
\hline Alona & 7.84 & 10.41 & 7.69 & 12.50 \\
\hline Chydorus & 7.84 & 8.33 & 7.69 & 3.84 \\
\hline Daphnia & 5.88 & 4.16 & 12.8 & 0.96 \\
\hline Total species & 51 & 48 & 39 & 104 \\
\hline
\end{tabular}


esis has also been put forth for the Palaearctic elements seen in Thailand (Maiphae et al., 2008). Both these statements are conjectural for the moment and more studies are needed to confirm either of them.

Daphnia found in the study also have a varying distribution with species number changing latitudinally across regions, and follows a trend which has been analyzed in a recent study by Popova and Kotov (2013). D. (C.) lumholtzi is distributed in Africa, Asia and Australia but recently spread to North America (Benzie, 2005; Sorensen and Sterner, 1992) and South America (Kotov and Taylor, 2014). D. (C.) similoides extends from the Indian subcontinent to Central China (Hudec, 1991; Benzie, 2005) but recently it has been shown that China houses a distinct sub-species, D. (C.) similoides sinensis (Gu et al., 2013). Therefore, it is likely that $D$. (C.) similoides s.str, is endemic to the Indian subcontinent. Daphnia (Ctenodaphnia) carinata is known from South Asia, Australasia and Africa (Benzie, 2005). Subgenus Daphnia is rare in the tropics but becomes speciose towards the subtropics (Fernando, 1980; Fernando et al., 1987). Species from the subgenus Daphnia are found at lower latitudes but at higher altitudes (Dumont, 1994; Green, 1995; Kotov and Taylor, 2010; Van Damme and Eggermont, 2011). The absence of high altitudes in NWG and Sri Lanka is thus one of the reasons why Daphnia does not occur here. Nepal lies above $24^{\circ} \mathrm{N}$ with many Himalayan lakes at alpine altitudes over $4000 \mathrm{~m}$. Presence of Daphnia here surely reflects both altitude and latitude. Other factors that may restrict Daphnia in the tropics are relentless fish predation (Burks et al., 2000; Dumont, 1994; Green, 1995), invari-

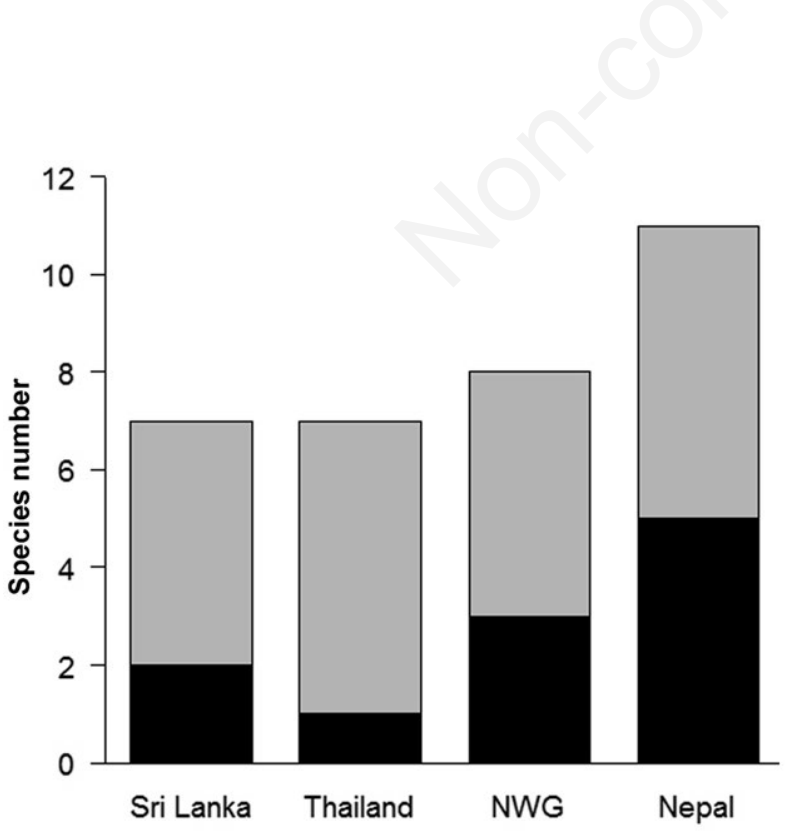

Fig. 3. Bargraph showing total Daphniid species for respective regions. Each bar represents total Daphniidae species; in black, number of Daphnia species; in gray, other members of the family. ably high temperatures (Allan and Goulden, 1980; Fernando, 1980; Dumont, 1994; Gillooly, 2000), and absence of a photoperiodic signal for sexual reproduction (Stross and Hill, 1968; Dumont, 1994; Kerfoot and Lynch, 1987; Chiambeng and Dumont, 2005).

The disparity in complementarity seen between the studied regions is likely due to the combination of altitude, latitude (and resulting variation in environmental variables) and dearth of taxonomic expertise, as discussed earlier. Thus, the fauna of Nepal has distinct faunal elements owing to its altitude and this fauna will likely increase with a better taxonomical investigation. Many species found in northeastern India (Sharma and Sharma, 1990, 2007, 2008 2009, $2011,2014)$ can also be expected in the tropical parts of Nepal since they are known from countries such as Thailand and Laos (Maiphae et al., 2008; Kotov et al., 2013; Van Damme and Sinev, 2013). This in turn could affect the complementarity value. Complementarity index is known to be sensitive to the comprehensiveness of the underlying census. The more inclusive the inventory, the more robust is the complementarity index derived from it (Colwell and Coddington, 1994).

NWG is facing problems such as rampant land conversion, eutrophication and invasive fish species. Temporary water habitats are destroyed at an alarming rate by anthropogenic activities (Williams, 2002). Data on such loss of temporary water bodies due to land conversion are not known for developing countries (Brendonck et al., 2008). Loss of small freshwater bodies could mean local extinction of species leading to a decrease in the regional diversity or even potential total extinction for endemic species (De Bie et al., 2008; Forró et al., 2008) like our Moina hemanti Ephemeral water bodies represented more than $50 \%$ of the total samples collected in the study (data available on request). Eutrophication leads to modification of the aquatic habitats and organization of zooplankton communities including Cladocera (Sampaio et al., 2002). Many habitats in the hills of the Western Ghats were relatively free of eutrophication but habitats within city limits were highly eutrophicated and with peculiar cladoceran fauna (C. cornuta and M. micrura dominated the plankton). Destructive effect of introduced fish species like guppy (Poecilia reticulata) on native fauna has been documented by Ghate and Padhye (1988) and could be affecting cladocerans in a similar manner.

\section{CONCLUSIONS}

We found 51 species of Cladocera in six families, with maximum number of species in the Chydoridae. Chao2 and Jackknife 2 indices showed that only few species were missed: $80 \%$ of the estimated species were recovered in the study. This is somewhat surprising, as it does not confirm the NWG as a biodiversity hotspot for cladocerans. Comparison of NWG fauna with other regions 
showed that NWG was most similar to Sri Lanka and least to Nepal, suggesting a latitudinal as well as an altitudinal gradient. Cladoceran family representation was similar across the compared regions but varied at species level. The number of Daphnia species increased with latitude, with occurrence of sub genus Daphnia only in Nepal. Most of the species found were circumtropical with only two endemics and a few Palaearctic elements. One of the endemics belongs to the rare group of cladocerans with a Tropical Amphi-Pacific distribution.

\section{ACKNOWLEDGMENTS}

Sameer Padhye would like to acknowledge Prof. Kalpana Pai and the Zoology Department of Pune University for providing the lab facilities, as sample collection studied in the paper was done during the Ph.D work of the author; he also acknowledges the Council of Scientific and Industrial Research (CSIR) for providing funding during his Ph.D. SP also thanks Dr. Alexey Kotov and Dr. K. Van Damme for providing literature and for commenting on a draft of the work during the FISA Workshop, Thailand, 2012; and he also acknowledges Dr. Satish Pandey, Dr. Anand Padhye, Mr. Vivek Vishwasrao and ELA Foundation, Pune for their help in collection of some water reservoir samples. The authors would thank Dr. Sanjay Molur, Dr. Neelesh Dahanukar and WILD for their support. HJD is a recipient of a grant of Top Talented Scientist of the Province of Guangdong, China, and thanks the regional government for support.

\section{REFERENCES}

Allan JD, Goulden CE, 1980. Some aspects of reproductive variation among freshwater zooplankton, p. 388-410. In: C.W. Kerfoot (ed.), Evolution and ecology of zooplankton communities. University Press of New England.

Belyaeva M, Taylor DJ, 2009. Cryptic species within the Chydorus sphaericus species complex (Crustacea: Cladocera) revealed by molecular markers and sexual stage morphology. Mol. Phylogenet. Evol. 50:534-546.

Benzie JAH, 2005. The genus Daphnia (including Daphniopsis) (Anomopoda: Daphniidae), p. 1-383. In: H.J. Dumont (ed.) Guides to the identification of the microinvertebrates of the continental waters of the world. SPB Academic Publishing.

Berner D, 1986. Taxonomy of Ceriodaphnia (Crustacea Cladocera) in U.S. Environmental Protection Agency Cultures, USEPA-600/4-86-032. Cincinnati, OH, USA.

Brendonck L, Rogers DC, Olesen J, Weeks S, Hoeh W R, 2008. Global diversity of large branchiopods (Crustacea: Branchiopoda) in freshwater. Hydrobiologia 595:167-176.

Burks RL, Jeppesen E, Lodge DM, 2000. Macrophyte and fish chemicals suppress Daphnia growth and alter life-history traits. Oikos 88:39-147.

Chao A, 1987. Estimating the population size for capture recapture data with unequal catchability. Biometrics 43:783-791.

Chatterjee T, Kotov AA, Van Damme K, Chandrasekhar SVA,
Padhye S, 2013. An annotated checklist of the Cladocera (Crustacea: Branchiopoda) from India. Zootaxa 3667:1-89.

Chiambeng GY, Dumont HJ, 2005. The Branchiopoda (Crustacea: Anomopoda, Ctenopoda and Cyclestherida) of the rain forests of Cameroon, West Africa: low abundances, few endemics and a boreal-tropical disjunction. J. Biogeogr. 32:1611-1620.

Colwell RK, 2013. Estimate S: Statistical estimation of species richness and shared species from samples, ver. 9. Available from: http://purl.oclc.org/estimates.

Colwell RK, Coddington JA, 1994. Estimating terrestrial biodiversity through extrapolation. Philos. T.R. Soc. B 345:101-118.

De Bie T, Declerck S, Martens K, De Meester L, Brendonck L, 2008. A comparative analysis of cladoceran communities from different water body types: patterns in community composition and diversity. Hydrobiologia 597:19-27.

Dumont HJ, 1980. Zooplankton and the science of biogeography: the example of Africa, p. 685-696. In W.C. Kerfoot (ed.), Evolution and ecology of zooplankton communities. University Press of New England.

Dumont HJ, 1994. On the diversity of the Cladocera in the tropics. Hydrobiologia 272:27-38.

Dumont HJ, Pensaert J, 1983. A revision of the Scapholeberinae (Crustacea: Cladocera). Hydrobiologia 100:3-45.

Dumont HJ, Segers H, 1996. Estimating lacustrine zooplankton species richness and complementarity. Hydrobiologia 314:125-132.

Dumont HJ, Van de Velde I, 1977. Report on collection of Cladocera and Copepoda from Nepal. Hydrobiologia 53:55-65.

Fernando CH, 1980. The freshwater zooplankton of Sri-Lanka, with a discussion of tropical freshwater zooplankton composition. Int. Revue Ges. Hydrobiol. 65:85-125.

Fernando CH, Kanduru A, 1984. Some remarks on the latitudinal distribution of Cladocera on the Indian subcontinent. Hydrobiologia 113:69-76.

Fernando CH, Paggi JC, Rajapaksa R, 1987. Daphnia in tropical lowlands. In: R.H. Peters and R. de Bernardi (ed.), Daphnia. Mem. Ist. Ital. Idrobiol. 45:107-141.

Forró L, Korovchinsky NM, Kotov AA, Petrusek A, 2008. Global diversity of cladocerans (Cladocera; Crustacea) in freshwater. Hydrobiologia 595:177-184.

Frey DG, 1986. The non-cosmopolitanism of chydorid Cladocera: implications for biogeography and evolution, p. 237256. In: R.H. Gore and K.L. Heck (eds.), Crustacean biogeography. A.A. Balkema.

Frey DG, 1987. The taxonomy and biogeography of the Cladocera. Hydrobiologia 145:5-17.

Ghate HV, Padhye AD, 1988. Predation of Microhyla tadpoles by Gambusia. J. Bombay Nat. Hist. Soc. 85:200-201.

Gillooly JF, 2000. Effect of body size and temperature on generation time in Zooplankton. J. Plankton Res. 22:241-251.

Goulden CE, 1968. The systematics and evolution of the Moinidae. Trans. Am. Phil. Soc. 58:1-101.

Green J, 1995. Altitudinal distribution of tropical planktonic Cladocera. Hydrobiologia 307:75-84.

Gu YL, Xu L, Li QQ, Dumont HJ, Han BP, 2013. A new subspecies of Daphnia: Daphnia similoides sinensis. Ecol. Sci. 32:308-312.

Hudec I, 1991. A comparison of populations from the Daphnia similis group (Cladocera: Daphniidae). Hydrobiologia 225:9-22. 
Kerfoot WC, Lynch M, 1987. Branchiopod communities: association with planktivorous fish in space and time, p. 367378. In: W.C. Kerfoot and A. Sih (eds.), Predation: direct and indirect impacts on aquatic communities. University Press of New England.

Korovchinsky NM, 1992. Sididae \& Holopediidae, p. 1-82. In: H.J. Dumont (ed.), Guides to the identification of the microinvertebrates of the continental waters of the world. 3 . SPB Academic Publ.

Korovchinsky NM, 2006. The Cladocera (Crustacea: Branchiopoda) as a relict group. Zool. J. Linn. Soc. 147:109-124.

Korovchinsky NM, 2013. Cladocera (Crustacea: Branchiopoda) of South East Asia: history of exploration, taxon richness and notes on zoogeography. J. Limnol. 72(Suppl.2):109-124.

Kotov AA, 2000. Re-description and assignment of the chydorid Indialona ganapati Petkovski, 1966 (Branchiopoda: Anomopoda: Aloninae) to Indialonini, new tribus. Hydrobiologia 439:161-178.

Kotov AA, 2011. Crustacea - Cladocera checklist. Available from: http://fada.biodiversity.be/ CheckLists/Crustacea Cladocera.pdf

Kotov AA, Elias-Gutierrez M, Granados-Ramírez JG, 2005. Moina dumonti sp. nov. (Cladocera, Anomopoda, Moinidae) from southern Mexico and Cuba, with comments on moinid limbs. Crustaceana 78:41-57.

Kotov AA, Stifter P, 2006. Ilyocryptidae of the world, p. 1-172. In: H.J. Dumont (ed.), Guides to the identification of the microinvertebrates of the continental waters of the world, 22. Backhuys Publ.

Kotov AA, Taylor DJ, 2010. A new African lineage of the Daphnia obtusa group (Cladocera: Daphniidae) disrupts continental vicariance patterns. J. Plankton Res. 32:937-949.

Kotov AA, Taylor DJ, 2014. Daphnia lumholtzi Sars, 1885 (Cladocera: Daphniidae) invades Argentina. J. Limnol. 73:369-374.

Kotov AA, Van Damme K, Bekker EI, Siboualipha S, Silva-Briano M, Ortiz AA, De La Rosa RG, Sanoamuang L, 2013. Cladocera (Crustacea: Branchiopoda) of Vientiane province and municipality, Laos. J. Limnol. 72(Suppl.2):81-108.

Maiphae S, Pholpunthin P, Dumont HJ, 2005. Species richness of the Cladocera (Branchiopoda: Anomopoda and Ctenopoda) in southern Thailand, and its complementarity with neighboring regions. Hydrobiologia 637:147-156.

Maiphae S, Pholpunthin P, Dumont HJ, 2008. Taxon richness and biogeography of the Cladocera (Crustacea: Ctenopoda, Anomopoda) of Thailand. Int. J. Limnol. 44:33-43.

Mani MS, 1974. Ecology and biogeography in India. W. Junk Publ.: 647 pp.

Manca M, Martin P, Carolina DP, Benzie JAH, 2006. Re-description of Daphnia (Ctenodaphnia) from lakes in the Khumbu Region, Nepalese Himalayas, with the erection of a new species, Daphnia himalaya, and a note on an intersex individual. J. Limnol. 65:132-140.

Michael RG, Sharma BK, 1988. Fauna of India and adjacent countries, Indian Cladocera (Crustacea: Branchiopoda: Cladocera). Zoological Survey of India: $262 \mathrm{pp}$.

Mittermeier RA, Gil PR, Hoffman M, Pilgrim J, Brooks T, Brooks, Mittermeier CG, Lamoreux J, da Fonseca GAB, 2005. Hotspots revisited: Earth's biologically richest and most endangered terrestrial ecoregions. Cemex: 392pp.
Myers N, Mittermeier RA, Mittermeier CG, da Fonseca GAB, Kent J, 2000. Biodiversity hotspots for conservation priorities. Nature 403:853-858.

Orlova-Bienkowskaja MY, 2001. Daphniidae: genus Simocephalus, p. 1-130. In: H.J. Dumont (ed.), Guides to the identification of the microinvertebrates of the continental waters of the world, 17. Backhuys Publ.

Padhye SM, Dumont HJ, 2014. Moina hemanti n. sp., a new species of the genus Moina s.l. (Branchiopoda: Anomopoda) from Pune, India. Zootaxa 3860:561-570.

Patil GP, Kedar GT, Yeole SM, 2008. Zooplankton biodiversity study of two waterbodies in Washim district, Maharashtra. J. Aquat. Biol. 23:13-17.

Patil SS, Auti RG, Mokashe SS, 2008. Conservation and management of Salim Ali Lake, Aurangabad, p. 1614-1622. In: M. Sengupta and R. Dalwani (eds.), Proceedings of Taal 2007, $12^{\text {th }}$ World Lake Conference.

Petrusek A, Černy M, Audenaert E, 2004. Large intercontinental differentiation of Moina micrura (Crustacea: Anomopoda): one less cosmopolitan cladoceran? Hydrobiologia 526:3-81.

Popova EY, Kotov AA, 2013. Latitudal patterns in the diversity of two subgenera of the genus Daphnia O.F. Müller (Crustacea: Cladocera: Daphniidae). Zootaxa 3736:59-174.

Rane P, 2002. Cladocera: crustacea zoological survey of India wetland ecosystem series. Fauna of Ujani 3:71-85.

Rane P, 2009. Zoological survey of India, Fauna of Bhimashankar wildlife sanctuary. Conservation Area Series 42:263-272.

Rane P, 2013. Cladocera, p. 1-673. In: Z.S.I. Kolkata (ed.), Fauna of Maharashtra. Zool. Survey of India, State Fauna Series.

Sampaio EV, Rocha O, Matsumura-Tundisi T, Tundisi JG, 2002. Composition and abundance of zooplankton in the limnetic zone of seven reservoirs of the Paranapanema River, Brazil. Braz. J. Biol. 62:525-545.

Sharma BK, Sharma S, 1990. On the taxonomic status of some cladoceran taxa (Crustacea: Cladocera) from Central India. Rev. Hydrobiol. Trop. 23:105-113.

Sharma BK, Sharma S, 2005. Faunal diversity of Rotifers (Rotifera: Eurotatoria) of Deepor Beel, Assam (N. E. India) - a Ramsar site. J. Bombay Nat. Hist. Soc. 102:69-175.

Sharma BK, Sharma S, 2007. New records of two interesting chydorid cladocerans (Branchiopoda: Cladocera: Chydoridae) from flood plain lakes of Assam, India. Zoos' Print J. 22:2799-2801.

Sharma BK, Sharma S, 2008. Zooplankton diversity in floodplain lakes of Assam. Rec. Zool. Surv. India 290:141-307.

Sharma BK, Sharma S, 2009. Faunal diversity of Cladocera (Crustacea: Branchiopoda) of Loktak Lake (a Ramsar site), Manipur (N.E. India). J. Bombay Nat. Hist. Soc. 106:156-161.

Sharma BK, Sharma S, 2011. Faunal diversity of Cladocera (Crustacea: Branchiopoda) of Nokrek Biosphere Reserve, Meghalaya, northeastern India. J. Threatened Taxa 3:21202127.

Sharma BK, Sharma S, 2014. Faunal diversity of Cladocera (Crustacea: Branchiopoda) in wetlands of Majuli (the largest river island), Assam, northeast India. Opusc. Zool. Budapest 45:1-9.

Sinev AY, 1999. Alona costata Sars, 1862 versus related palaeotropical species: the first example of close relations between species with a different number of main head pores 
among Chydoridae (Crustacea: Anomopoda). Arthropoda Selecta 8:131-148.

Sinev AY, 2001. Separation of Alona cambouei Guerne \& Richard, 1893 from Alona pulchella King, 1853 (Branchiopoda, Anomopoda, Chydoridae). Arthropoda Selecta 10:5-18.

Sinev AY, 2011. Redescription of the rheophilous Cladocera Camptocercus vietnamensis Than, 1980 (Cladocera: Anomopoda: Chydoridae). Zootaxa 2934:53-60.

Sinev AY, 2012. Alona kotovi sp. nov., a new species of Aloninae (Cladocera: Anomopoda: Chydoridae) from South Vietnam. Zootaxa 3475:45-54.

Smirnov NN, 1971. [Chydoridae of the world fauna. Fauna SSSR].[Book in Russian] Rakoobraznie 1:1-531.

Smirnov NN, 1992. The Macrothricidae of the world, p. 1-143. In H.J. Dumont (ed.), Guides to the identification of the microinvertebrates of the continental waters of the world, 17. SPB Academic Publ.

Smirnov NN, 1996. Cladocera: the Chydorinae and Sayciinae (Chydoridae) of the world, p. 1-197. Guides to the identification of the microinvertebrates of the continental waters of the world, 17. SPB Academic Publ.

Sorensen KH, Sterner RW, 1992. Extreme cyclomorphosis in Daphnia lumholtzi. Freshwater Biol. 28:257-262.

Stross RG, Hill JC, 1968. Photoperiod control of winter diapause in the fresh-water Crustacean, Daphnia. Biol. Bull. 134:76-198.

Swar DB, Fernando CH, 1979. Cladocera from Pokhara Valley, Nepal with notes on distribution. Hydrobiologia 66:113-128.
Van Damme K, Dumont HJ, 2008. The 'true' genus Alona Baird, 1843 (Crustacea: Cladocera: Anomopoda): characters of the A. quadrangularis-group and description of a new species from Democratic Republic Congo. Zootaxa 1945:1-25.

Van Damme K, Eggermont H, 2011. The Afromontane Cladocera (Crustacea: Branchiopoda) of the Rwenzori (UgandaD.R. Congo): ecology, biogeography and taxonomy including the description of Alona sphagnophila n. sp. Hydrobiologia 676:57-100.

Van Damme K, Kotov AA, Dumont HJ, 2010. A checklist of names in Alona Baird, 1843 (Crustacea: Cladocera: Chydoridae) and their current status: an analysis of the taxonomy of a lump genus. Zootaxa 2330:1-63.

Van Damme K, Sinev AY, 2013. Tropical amphi-pacific disjunctions in the Cladocera (Crustacea: Branchiopoda). J. Limnol. 72(Suppl.2):209-244.

Van Damme K, Sinev AY, Dumont HG, 2011. Separation of Anthalona gen.n. from Alona Baird, 1843 (Branchiopoda: Cladocera: Anomopoda): morphology and evolution of scraping stenothermic alonines. Zootaxa 2875:1- 64.

Vanjare AI, Padhye SM, Pai K, 2010. Zooplankton from a polluted river, Mula (India),with record of Brachionus rubens (Ehrenberg, 1838) epizoic on Moina macrocopa (Straus, 1820). Opusc. Zool. Budapest 41:89-92.

Williams DD, 2002. Temporary water crustaceans: biodiversity and habitat loss, p. 223-233. In: E. Escobar-Briones and F. Alvarez (eds.), Modern approaches to the study of Crustacea. Kluwer, Dordrecht. 